\title{
SOEP
}

SOEPpapers

SOEPpapers
on Multidisciplinary Panel Data Research
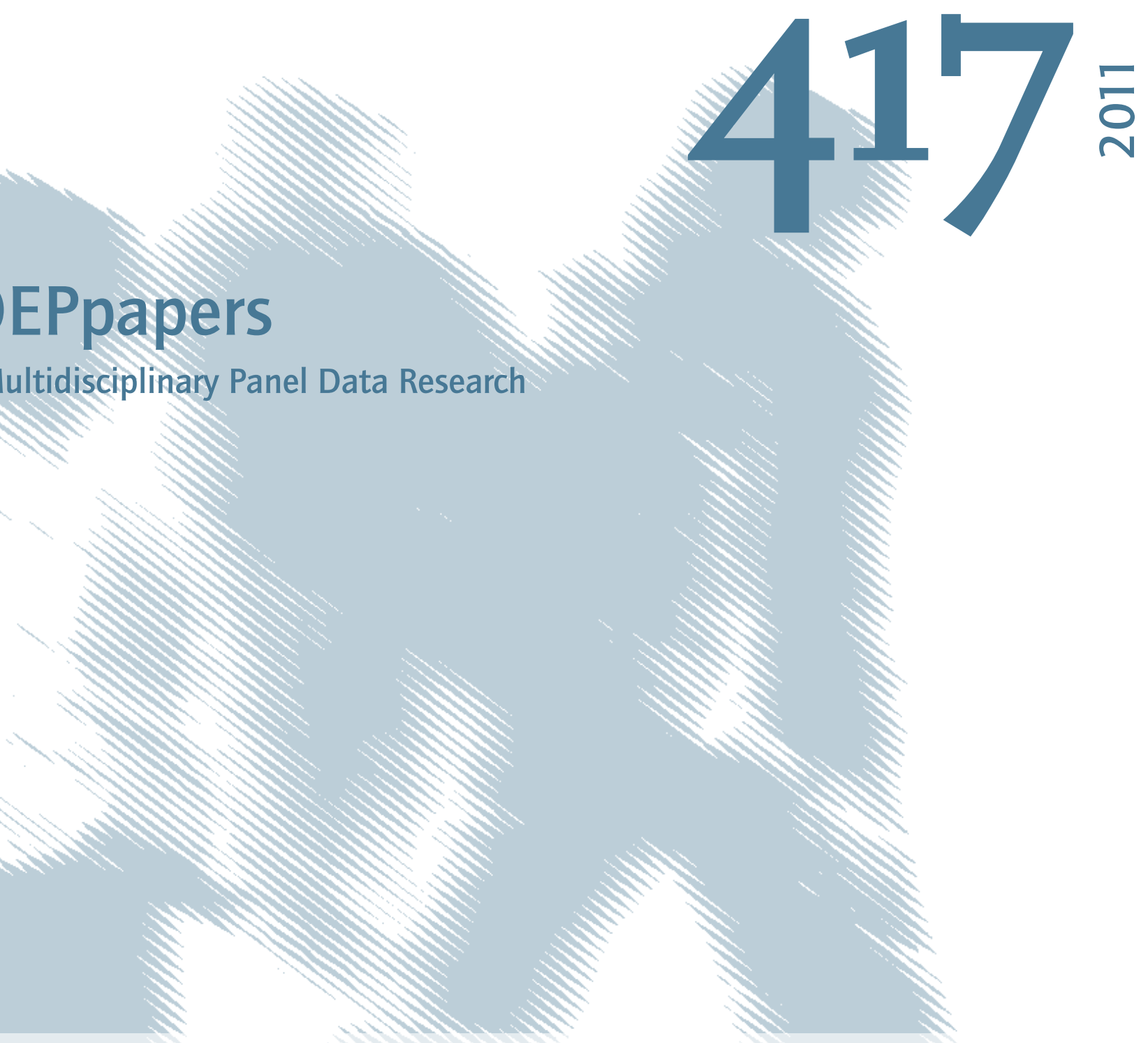

\section{Self-employment and geographical mobility in Germany}




\section{SOEPpapers on Multidisciplinary Panel Data Research}

at DIW Berlin

This series presents research findings based either directly on data from the German SocioEconomic Panel Study (SOEP) or using SOEP data as part of an internationally comparable data set (e.g. CNEF, ECHP, LIS, LWS, CHER/PACO). SOEP is a truly multidisciplinary household panel study covering a wide range of social and behavioral sciences: economics, sociology, psychology, survey methodology, econometrics and applied statistics, educational science, political science, public health, behavioral genetics, demography, geography, and sport science.

The decision to publish a submission in SOEPpapers is made by a board of editors chosen by the DIW Berlin to represent the wide range of disciplines covered by SOEP. There is no external referee process and papers are either accepted or rejected without revision. Papers appear in this series as works in progress and may also appear elsewhere. They often represent preliminary studies and are circulated to encourage discussion. Citation of such a paper should account for its provisional character. A revised version may be requested from the author directly.

Any opinions expressed in this series are those of the author(s) and not those of DIW Berlin. Research disseminated by DIW Berlin may include views on public policy issues, but the institute itself takes no institutional policy positions.

The SOEPpapers are available at

http://www.diw.de/soeppapers

\section{Editors:}

Joachim R. Frick (Empirical Economics)

Jürgen Schupp (Sociology, Vice Dean DIW Graduate Center)

Gert G. Wagner (Social Sciences)

Conchita D'Ambrosio (Public Economics)

Denis Gerstorf (Psychology, DIW Research Professor)

Elke Holst (Gender Studies)

Frauke Kreuter (Survey Methodology, DIW Research Professor)

Martin Kroh (Political Science and Survey Methodology)

Frieder R. Lang (Psychology, DIW Research Professor)

Henning Lohmann (Sociology, DIW Research Professor)

Jörg-Peter Schräpler (Survey Methodology, DIW Research Professor)

Thomas Siedler (Empirical Economics, DIW Graduate Center)

C. Katharina Spieß (Empirical Economics and Educational Science)

ISSN: 1864-6689 (online)

German Socio-Economic Panel Study (SOEP)

DIW Berlin

Mohrenstrasse 58

10117 Berlin, Germany

Contact: Uta Rahmann | soeppapers@diw.de 


\title{
Self-employment and geographical mobility in Germany
}

\section{Darja Reuschke}

\begin{abstract}
Little is known about the individual location behaviour of self-employed entrepreneurs. This paper investigates the geographical mobility behaviour of self-employed entrepreneurs, as compared to employees, thereby shedding new light onto the place embeddedness of selfemployment. It examines whether self-employed entrepreneurs are 'rooted' in place and also whether those who are more rooted in place are more likely to enter self-employment. The paper draws on large-scale panel data covering the years 1996-2009 from the German SocioEconomic Panel Study (SOEP). It shows that self-employed entrepreneurs as compared to employees are not more 'rooted' in their place of residence and that those who are more rooted in their place of residence are not more likely to become self-employed. However, in contrast to expectations drawn from previous literature, flows into self-employment are positively associated with inter-regional moves. It concludes that a longitudinal perspective on individual employment careers provides an important methodological advance. In addition, it emphasises the importance of mobility and immobility and individual and household constraints and preferences for understanding who becomes self-employed.
\end{abstract}

JEL: C23, J21, J61, J62, R23

Keywords: self-employment, migration, moves, panel data, SOEP, Germany

\section{Darja Reuschke}

University of St Andrews, School of Geography \& Geosciences The Observatory Buchanan Gardens

St Andrews, Fife KY16 9LZ, United Kingdom

E-mail: darja.reuschke@st-andrews.ac.uk

Phone: $++44(0) 1334467325$

Fax: $++44(0) 1334467298$ 


\section{Self-employment and geographical mobility in Germany}

\section{Introduction}

There is consensus in the literature that entrepreneurship is a 'local' event (Audretsch et al. 2010; Feldman et al. 2005; Romanelli and Schoonhaven 2001; Sorenson and Audia 2000; Stam 2007; Tamásy 2006). This embeddedness is thought to be connected to individual entrepreneurs being strongly 'rooted' in their place of residence (Hanson 2003, 18). Most research, however, is focused on firms and firm formation rather than individual entrepreneurs (e.g., Armington and Acs 2002; Delgado et al. 2010; Fritsch and Schindele 2011). Those studies that do use individual micro data (for example, the Global Entrepreneurship Monitor) lack comparative and longitudinal research designs (e.g., Bergmann and Sternberg 2007; Hanson 2003, 2009; Wagner 2007).

Hence, little is known about the direction of causality between self-employment and place embeddedness. On the one hand, people who are more rooted in place, for instance due to a desire to stay close to other family members, could be more likely to become self-employed. Contrary to this, location-specific capital required for self-employment might make selfemployed entrepreneurs 'stuck' in place. Knowledge on this inter-relationship is thus important for our understanding of the features and dynamics of self-employment. This is of relevance not only for entrepreneurship policy but also for understanding the functioning of regional labour markets. Panel surveys are a powerful resource to investigate these peopleplace relations of self-employment since panel data provide information about the temporal ordering of events and are therefore more useful than cross-sectional data in establishing causal relationships (Frees 2004, 11).

This paper aims to shed new light on the inter-relationship between self-employment and place by drawing attention to the spatial behaviour of self-employed entrepreneurs, as 
opposed to workers in paid employment. It explores (1) whether self-employed entrepreneurs are 'rooted' in place and (2) whether those who are more 'rooted' in their place of residence are more likely to become self-employed. Cross-sectional micro data (for example, the Global Entrepreneurship Monitor) is not suitable to answer these questions. This paper therefore draws on large-scale longitudinal data for Germany. The limitation of defining entrepreneurship through self-employment notwithstanding (see, for example, Parker 2006, 436-437; Reynolds 1997, 451), it uses the self-employment status as category which is a common method in entrepreneurship research (e.g., Blanchflower and Meyer 1994; Georgellis et al. 2005; Joona and Wadensjö 2011; Millán et al. 2010; Mueller 2006; Parker 1997).

This paper contributes to the existing literature in several ways. Panel surveys are generally under-used in entrepreneurship research (Davidsson and Gordon 2011). Consequently, most existing studies explore entrepreneurship or self-employment only in relation to the place/regional environment in which business founders and entrepreneurs currently reside (see also Wai-chung Yeung 2009, 212). The novel linkage between self-employment and residential moves over time this paper offers will provide an empirical basis for a "new dialogue on spaces of entrepreneurship" that recent literature has called for (Stam 2007; Waichung Yeung 2009, p. 213). Furthermore, using micro data to explore inter-relations between self-employment and place will add to the literature an individual perspective on entrepreneurial location behaviour.

The remainder of this paper is organised as follows: The next section examines the theoretical arguments linking self-employment/entrepreneurship to place, specifying some expectations regarding the geographical mobility behaviour of self-employed entrepreneurs. Section 3 describes the data the empirical analysis is based on. Empirical results are presented in section 4. The concluding section (5) summarises and discusses the results, identifying some implications for future research. 


\section{Literature review, theoretical background and hypotheses}

There is a rich literature that explains the 'location inertia' of entrepreneurship and why people tend to launch business on 'home turf' (Hanson and Blake 2009, 143) through location-specific capital in terms of social networks. Agglomeration economies and cluster theory suggest that face-to-face contacts, localised personal relationships and thick social networks (social capital) stimulate spatial agglomeration and cluster development by inducing external economies, i.e. additional economic benefits. It is argued that start-up firms benefit from these local externalities in terms of knowledge spillovers, for example, through frequent contacts to other entrepreneurs in related industries (Acs and Armington 2004; Armington and Acs 2002; Delgado et al. 2010; Feldman 2001; Malmberg and Maskell 2002; Thornton and Flynn 2003; Varga and Schalk 2004). This local interexchange of information, learning and innovation is considered as 'seedbed' for tacit knowledge (i.e. non-codified individual experiences and insights) (Scott 2006). In contrast, formal, codified knowledge is perceived to be easily transferable over long distances or, in other words, distance networks relate to formal knowledge that can be exchanged by technological means (Varga and Schalk 2004). Similarly, economic geographers point to the evolutionary process of networks and thus to the socioeconomic embeddedness of start-up activities. Consequently, the process of setting up a business is not regarded as a 'real' locational decision as it is argued that the business location is constrained by the place where the founder lives and works (Bathelt and Glückler 2002, p. 207; Glückler 2007). Hence, it can be assumed that residential tenure and not just geographical proximity to other businesses, suppliers, etc. matters for self-employed entrepreneurs since localised network externalities are tangible, non-transferable assets (Varga and Schalk 2004).

It is not clear, however, what types of network ties are important over the different stages of establishing a business. Some studies find evidence for the importance of strong ties and the 
geographical proximity to family members, relatives and friends in supporting people, particularly women, to become self-employed as well as in running a business once it is established (Abraham 2006; Ekinsmyth 2011; Hanson 2009; Jack 2005). Others emphasise the role of weak ties for entrepreneurship, for example through access to information and financial resources via contacts to accountants, bank loan officers, peers etc. (e.g., Bönte et al. 2009; Katz and Williams 1997; Nijkamp 2003). Econometric studies reveal the importance of the entrepreneurial family background for self-employment (Lohmann and Luber 2004; Niittykangas and Tervo 2005; Shutt and Sutherland 2003; Taylor 1996). People with at least one self-employed parent are more likely to be self-employed, supporting the strong ties hypothesis and the crucial role of close relations to family members for the geography of selfemployment. As a result, one could expect to find evidence that self-employed entrepreneurs are highly embedded in their local context in terms of geographical proximity to close family members.

Recent research found that the rootedness or embeddedness of entrepreneurship is also to be influenced by personal constraints and preferences of the business owner. Feldman (2001), for example, highlights the hampering effect of the household and family context in binding selfemployed entrepreneurs to their place of residence. From this perspective one could also understand self-employment/entrepreneurship as a mean to avoid a family move. As regards personal preferences, Florida's (2002) theory about the 'creative class' and its preferences to live in the hot spots of urban creativity and amenities also include some ideas on 'creative' self-employed entrepreneurs. This might imply geographical moves of a certain type of selfemployed entrepreneur to fulfil residential location preferences.

Only few studies to date, however, have empirically explored the place relations of individual entrepreneurs. Michelacci and Silva (2007) provide evidence supporting the rootedness or embeddedness of entrepreneurship from the U.S. and Italy. They found that the proportion of 
people who work in the region where they were born is significantly higher among the selfemployed than among dependent workers. These results are in accordance with the findings of Hanson (2003), who conducted two case studies in the USA. In her sample, business owners had longer residential tenures than the general population and also exhibited a high tendency to remain close to their family roots. Blanchflower's (2000) investigation of the willingness to move by employment status in a number of OECD countries (excluding Germany) shows a similar picture, as the self-employed appear to be less willing than employees to move neighbourhood, town within the county, or region.

In contrast, Harrison et al.'s (2004) case study from a technology cluster in Ottawa (Canada) tells a different story of business owners' geographical mobility behaviour. Here, most of the business founders worked close to their present firm location immediately prior to the firm formation. However, many of these founders had previously moved to the region during their employment history and were born elsewhere. The authors therefore argue that previous studies have overestimated the local attachment of entrepreneurship. A number of studies in labour economics and industry economies support the importance of employment experiences for setting up a business (e.g., Feldman 2001; Knight and McKay 2000; Oberschachtsiek 2010; Taylor 1999). Therefore it seems likely that self-employed entrepreneurs are not 'rooted' in place but have moved earlier in their professional career in order to accumulate working experiences and professional skills as a prerequisite for entering selfemployment/setting up an own business.

Problematically, existing studies which provide some empirical evidence about the peopleplace relations of self-employment/entrepreneurship exhibit some methodological weaknesses. The study by Michelacci and Silva (2007) is constrained by a dependence on household level data (i.e. the selection of the — usually male — head of the household) and the authors' focus only on "real" start-ups (i.e. family businesses were excluded from the 
sample). Case studies are generally restricted to certain cases/industries, especially if no comparison group analysis was incorporated into the sample design (e.g., Feldman 2001; Hanson 2003; Harrison et al. 2004).

In summary, given the importance of both strong (family) ties and social contacts to the wider business community for setting up a business highlighted in previous research, it can be assumed that (1) self-employed entrepreneurs are more likely to remain in their place of residence than employees, (2) business founders have a lower propensity to move than those in continuous paid employment, and (3) self-employed entrepreneurs are more likely to live in close geographical proximity to family members than employees. The literature review suggests that people are more likely to set up their own business where they have lived and worked for a length of time. Thus one would expect that (4) those who do not move are more likely to become self-employed and that particularly employees who did not move are more likely to enter self-employment than non-moving employees.

\section{Data sources and methodological remarks}

This paper draws on data from the German Socio-Economic Panel Study (SOEP). The SOEP is a nationally representative annual household panel survey of private households which is operated by the German Institute for Economic Research (DIW Berlin). The SOEP started in 1984 in West Germany, when more than 12,000 individuals aged 16 or older were interviewed for the first time. In the SOEP, the same individuals are re-interviewed each successive year after they were first contacted. If individuals move out from the interviewed household to form a new household they are captured as an independent household in the sample, with all adult household members in the new household unit (aged 16 years and older) completing interviews. A total of 26 waves of SOEP data are currently available (1984-2009), but it was not until the year 1996 that the subsample of non-Germans 
('foreigner sample') and East Germans are posted the same questions and are kept in the same files. The extracted subsamples therefore consist of the waves $M$ to $Z$ covering the years 1996-2009.

The SOEP provides a rich source of micro-level data, although there may be a problem with sample attrition (as with all panel datasets) (Solga 2001). Movers are traced in the SOEP within Germany, but panel attrition is generally higher among movers than among nonmovers as in other panel surveys (Buck 2000). This is reflected in the small numbers of interregional movers in the SOEP, again as in other household panel surveys. Panel attrition due to a residential move may be problematic if the sample attrition of movers is non-random. Previous research has found no evidence for the non-random attrition of movers in the equivalent British Household Panel Survey (BHPS) (Rabe 2009; Rabe and Taylor 2010, p. 538). Due to the same research design and similar efforts being undertaken to trace movers, this can also assumed to be true for the SOEP. However, the data analysis is-pooled data notwithstanding - limited by the small number of inter-regional movers in the SOEP. Hence, the relations between self-employment and geographical mobility cannot be investigated on a more disaggregated level (sex, industry, occupation, numbers of employees, etc.).

The distinction between self- and paid employment (both for the main and the second job) relies on self-reporting by respondents. In the context of the present study, the categorisation of employment status is based on a person's main job, i.e. the job which can be considered the most important for their geographical mobility decisions. People who are employed in their (self-reported) main job and self-employed in their second job are therefore classified as employees. From this it follows that people are defined as self-employed if they consider themselves first and foremost as being self-employed. That means that they generate their main personal income from self-employed work and/or that they primarily work for themselves in terms of working hours. This includes all types of self-employment: agricultural 
and non-agricultural workers, persons who inherited a family business, owners of a firm with many employees as well as self-employed entrepreneurs who only create jobs for themselves. This is in line with most studies in labour economics (e.g., Blanchflower 2000; Parker 2006). At each wave, the survey questionnaire captures a residential move in the previous year. The place of residence is consistently recorded at the regional level, which resembles the Federal States (NUTS1 level regions, representing 16 administrative regions). This allows a distinction between moves across Federal States - inter-regional moves - and all other moves within Federal States. A distance variable for moves is only available from the year 2001 onwards. Hence, using distance-which would be without doubt a more accurate measurement of inter-regional moves - would reduce the number of waves that can be pooled and thus would reduce the number of migration events in the study sample considerably. As a result, no reliable investigation of geographical mobility accounting for employment status (self-employed vs. employed) could be carried out. For the purpose of this study, interregional moves are therefore defined as moves across regional borders.

The SOEP wave 23 (2006) captures questions on the geographical proximity to close family members. Since these questions are asked only in this wave, the effects on the employment status cannot be estimated. This data limitation notwithstanding, a cross-sectional exploration can offer some insights into the importance of geographical proximity to close family members for self-employment. The geographical distance to close family members was measured through seven items for each family member (in the same household; in the same residential building; in the same neighbourhood; in the same town, but more than 15 minutes away by foot; in another town but within one hour drive; farther away but in Germany; abroad). For the purpose of this study, these were collapsed into two: in the same town vs. farther away that is a one hour drive and more or abroad. If the respondents had more than one sibling, only the distance to the nearest-residing sibling was recorded. 
Only people who are aged 18-64 and not in full-time education or (early) retirement for whom information on employment status, moving status and region of residence are available were selected. This results in a sample that contains 149,551 person-year observations for 23,886 individuals (i.e. repeated information are given for the same individuals). Out of the total number of person-years, there are 11,935 self-employed, 13,299 moves and 1,340 interregional migration events. Out of those who migrated 94 are self-employed and 901 are employed. A full description of the subsample of self-employed workers disaggregated by sex can be found in the appendix.

\section{Empirical results}

\subsection{Probability of moving}

In order to investigate whether self-employed workers as compared to employees are more 'rooted' in their place of residence two modelling techniques are used. In a first set of models the probability of having moved for the self-employed and employees in the previous year is estimated ( $t-1$ to $t$ ). A second set of models estimates the probability of a move between $t$ and $t+1$ for business founders as compared to workers in continuous paid employment. Unlike the first set of models (that includes all self-employed entrepreneurs as compared to employees) the second set of models only incorporates those self-employed entrepreneurs who recently set-up their own business. This allows to estimate the effect an entry into self-employment has on individual's geographical moving behaviour. For both sets of models random effects models are used. Unlike in simple OLS regression models the estimated coefficients in random-effects panel models are based on variations within and between the individuals over time (Kohler and Kreuter 2009, p. 248). Therefore this modelling technique allows controlling for individual heterogeneity. 
Table 1: Probability of moving $t-1$ to $t$ by type of move, self-employed and employed workers, random effects, odds ratios

\begin{tabular}{|c|c|c|c|c|}
\hline \multirow[b]{2}{*}{ Features at $t$} & \multicolumn{2}{|c|}{$\begin{array}{c}\text { Model } 1 \\
\text { move }=1 \text { vs. } \\
\text { no move }=0\end{array}$} & \multicolumn{2}{|c|}{$\begin{array}{c}\text { Model } 2 \\
\text { interreg. move }=1 \text { vs. no } \\
\text { interreg. move }=0\end{array}$} \\
\hline & OR & S.E. & OR & S.E. \\
\hline Self-employed (ref.: employed) & $1.089 * *$ & 0.044 & 1.021 & 0.131 \\
\hline Sex (ref:: men) & $0.931 * * *$ & 0.022 & $0.877 *$ & 0.067 \\
\hline Age (years) & $0.939 * * *$ & 0.001 & $0.938 * * *$ & 0.004 \\
\hline \multicolumn{5}{|l|}{$\begin{array}{l}\text { Household composition } \\
\text { (ref.: } 1 \text { Pers } h \text { ) }\end{array}$} \\
\hline Couple, no children & $0.780 * * *$ & 0.026 & $0.730 * * *$ & 0.070 \\
\hline Couple with children & $0.461 * * *$ & 0.015 & $0.367 * * *$ & 0.037 \\
\hline Single Parent & $0.748 * * *$ & 0.040 & $0.312 * * *$ & 0.068 \\
\hline Others & $0.331 * * *$ & 0.032 & $0.625 *$ & 0.151 \\
\hline Owner occupation $(n o=0$, yes $=1)$ & $0.509 * * *$ & 0.014 & $0.426 * * *$ & 0.039 \\
\hline \multicolumn{5}{|l|}{$\begin{array}{l}\text { CASMIN levels } \\
\text { (ref.: Higher tertiary degree) }\end{array}$} \\
\hline No completed general education & 0.949 & 0.092 & $0.222 * * *$ & 0.097 \\
\hline Elementary & $0.812 * * *$ & 0.045 & $0.231 * * *$ & 0.051 \\
\hline Basic vocational & $0.783 * * *$ & 0.030 & $0.269 * * *$ & 0.034 \\
\hline Middle general & $0.708 * * *$ & 0.054 & $0.384 * * *$ & 0.091 \\
\hline Middle vocational & $0.782 * * *$ & 0.028 & $0.434 * * *$ & 0.045 \\
\hline High general & $0.739 * * *$ & 0.056 & $0.527 * * *$ & 0.108 \\
\hline High vocational & $0.857 * * *$ & 0.041 & $0.554 * * *$ & 0.076 \\
\hline Lower tertiary & $0.857 * * *$ & 0.045 & $0.778^{*}$ & 0.109 \\
\hline Newly formed states $(n o=0$, yes $=1)$ & $0.946 * *$ & 0.025 & 0.875 & 0.073 \\
\hline N person-year observations (persons) & \multicolumn{2}{|c|}{$116,344(20,543)$} & \multicolumn{2}{|c|}{$116,344(20,543)$} \\
\hline $\mathrm{N}($ moves $)$ & \multicolumn{2}{|c|}{10,117} & \multicolumn{2}{|c|}{995} \\
\hline Log likelihood & \multicolumn{2}{|l|}{$-29,221$} & \multicolumn{2}{|l|}{$-4,828$} \\
\hline Rho (within subject correlation) & \multicolumn{2}{|l|}{0.029} & \multicolumn{2}{|l|}{0.300} \\
\hline Pseudo $\mathrm{R}^{2}$ & \multicolumn{2}{|l|}{0.096} & \multicolumn{2}{|l|}{0.096} \\
\hline
\end{tabular}

Notes: Pooled unweighted data SOEP 1996-2009. Self-employed workers and employees; moves and employment status are measured on a wave-to-wave basis. Significance: $* * * p \leq 0.01, * * p \leq 0.05, * p \leq 0.1$.

${ }_{1}$ International educational classification which considers the level of education in terms of length of educational experience and required abilities (elementary, secondary, higher) together with the vocational oriented qualification.

Source: author's calculation

Estimation results for the probability of having moved residence in the previous year among working people are displayed in Table 1. Model 1 estimates the determinants of moving between $t-1$ and $t$ as compared to the reference state of not moving residence. Model 2 explores the probability of an inter-regional move between $t-1$ and $t$ as compared to no interregional move. All explanatory variables are measured at wave $t$. In addition to the employment status (self-employed vs. employed) the models also include socio-economic features that are known for influencing individual's spatial behaviour (sex, age, 
education/qualification, and owner-occupation) as well as a dummy for residing in the newly formed states (without East Berlin) in order to account for significant differences between eastern and western Germany in terms of economic performance and employment. The results are displayed in odds ratios, which indicate the number by which one would multiply the odds of the group who moved between time $t-1$ and time $t$ for each one-unit increase in continuous predictor variables (while holding all other variables constant). Consequently, in Model 1 odds ratios greater than 1 indicate a greater chance and odds ratios less than 1 signify a lower chance of having moved residence than the reference category for each factor.

Contrary to the assumptions of previous literature using cross-sectional data, the estimation results in Table 1 demonstrate that self-employment increases the odds for having moved residence in the previous year by $9 \%$ (Model 1). As regards migration, the results show no difference between self-employed workers and workers in paid employment (Model 2). The odds ratio is nearly 1 , indicating whether workers are self-employed or employed has almost no effect on their probability to have moved residence inter-regionally in the previous year. Household composition, owner-occupation, gender, age, and educational/vocational qualification have the expected effects on individuals' probability to have moved/migrated; with the following being more likely to have moved or migrated: young workers, those with higher qualification and those living alone. Owner occupiers and women are less likely to have moved residence. The dummy for the newly formed states indicates that working people in eastern Germany are less likely to have moved within a State, although the effect is not significant for inter-regional moves.

The models presented in Table 2 explore further whether self-employment leads people to be less mobile by tracing business founders as compared to workers in continuous paid employment over time. To achieve this, a subsample was extracted from the SOEP across the waves 1996-2009 that consists of people who became self-employed between $t-1$ and $t$ and 
who remained self-employed until $t+1$ ('business founder') and persons who were employed between $t$ and $t+1$ ('continuous employee'). In total, the extracted sample contains 96,091 person-year observations. Out of those, 891 became self-employed between $t-1$ and $t$ and remained self-employed in $t+1$. The remaining person-year observations $(95,200)$ were continuously employed at $t$ to $t+1$. A total of 8,071 person-years involved moves, of which 731 were inter-regional.

Table 2: $\quad$ Probability of moving $t$ to $t+1$ by type of move, business founders and those in continuous paid employment, random effects, odds ratios

\begin{tabular}{|c|c|c|c|c|}
\hline \multirow[b]{2}{*}{ Features at $t$} & \multicolumn{2}{|c|}{$\begin{array}{c}\text { Model 1 } \\
\text { move }=1 \text { vs. } \\
\text { no move }=0\end{array}$} & \multicolumn{2}{|c|}{$\begin{array}{c}\text { Model } 2 \\
\text { interreg. move }=1 \text { vs. no } \\
\text { interreg. move }=0\end{array}$} \\
\hline & $\mathrm{OR}$ & S.E. & OR & S.E. \\
\hline $\begin{array}{l}\text { Business founder } \\
\text { (ref.: continuous employee) }\end{array}$ & 1.017 & 0.128 & 0.635 & 0.296 \\
\hline Sex $(r e f .:$ men $)$ & $0.911 * * *$ & 0.024 & $0.826^{* *}$ & 0.072 \\
\hline Age (years) & $0.940 * * *$ & 0.001 & $0.932 * * *$ & 0.004 \\
\hline \multicolumn{5}{|l|}{$\begin{array}{l}\text { Household composition } \\
\text { (ref.: } 1 \text { Pers } h \text { ) }\end{array}$} \\
\hline Couple, no children & $0.862 * * *$ & 0.035 & $0.563 * * *$ & 0.066 \\
\hline Couple with children & $0.936^{*}$ & 0.035 & $0.503 * * *$ & 0.057 \\
\hline Single Parent & $1.258 * * *$ & 0.074 & 0.824 & 0.158 \\
\hline Others & $1.341 * * *$ & 0.109 & 0.829 & 0.206 \\
\hline Owner occupation $($ no $=0$, yes $=1)$ & $0.215^{* * *}$ & 0.007 & $0.407 * * *$ & 0.042 \\
\hline \multicolumn{5}{|l|}{$\begin{array}{l}\text { CASMIN levels } \\
\text { (ref.: Higher tertiary degree) }\end{array}$} \\
\hline No completed general education & $0.736 * * *$ & 0.078 & $0.205 * * *$ & 0.108 \\
\hline Elementary & $0.675^{* * *}$ & 0.042 & $0.248 * * *$ & 0.062 \\
\hline Basic vocational & $0.735 * * *$ & 0.031 & $0.308 * * *$ & 0.044 \\
\hline Middle general & $0.730 * * *$ & 0.058 & $0.475 * * *$ & 0.119 \\
\hline Middle vocational & $0.772 * * *$ & 0.031 & $0.429 * * *$ & 0.052 \\
\hline High general & $0.832 * *$ & 0.068 & $0.690 *$ & 0.153 \\
\hline High vocational & $0.886^{* *}$ & 0.047 & $0.546 * * *$ & 0.087 \\
\hline Lower tertiary & $0.874 * *$ & 0.052 & 0.862 & 0.142 \\
\hline Newly formed states $($ no $=0$, yes $=1)$ & 0.979 & 0.029 & $1.181 *$ & 0.109 \\
\hline $\mathrm{N}$ person-year observations (persons) & \multicolumn{2}{|c|}{$93,246(17,467)$} & \multicolumn{2}{|c|}{$93,246(17,467)$} \\
\hline $\mathrm{N}$ (moves) & \multicolumn{2}{|c|}{8,071} & \multicolumn{2}{|c|}{731} \\
\hline Log likelihood & \multicolumn{2}{|l|}{$-23,382$} & \multicolumn{2}{|l|}{$-3,762$} \\
\hline Rho (within subject correlation) & \multicolumn{2}{|l|}{0.026} & \multicolumn{2}{|l|}{0.316} \\
\hline Pseudo $\mathrm{R}^{2}$ & \multicolumn{2}{|l|}{0.123} & \multicolumn{2}{|l|}{0.087} \\
\hline
\end{tabular}

Note: Pooled unweighted data SOEP 1996-2009. The sample consists of persons who became self-employed between $t-1$ and $t$ and who remained self-employed in the subsequent wave ('business founder') and persons who were employed at $t$ and $t+1$ ('continuous employee').

Source: author's calculation

Again, two models are displayed in Table 2, the first for all moves, irrespective of distance of move, and the second model for inter-regional moves. The outcome variables equal 1 if a 
person moves or migrates during $t$ to $t+1$ and zero if a person remains in the same residence (Model 1). In Model 2 only inter-regional moves are coded as 1, otherwise zero. The independent variable 'business founder' signifies whether a person became self-employed and has remained in self-employment or is continuously employed. All other variables (set of socio-structural features and dummy for newly formed states) in the regression models are measured at time $t$, i.e. before a possible move.

Model 1 in Table 2 suggests that business founders are not distinct from workers in continuous paid employment in their propensity to move residence in the subsequent year. A similar pattern emerges for inter-regional moves. The odds ratio for the business founder coefficient is lower than 1 but is not significantly different from zero. Furthermore, being of young age and having higher education/more training have the expected positive effects on the probability of moving/migrating. Owner-occupiers, women and individuals in couple and family households are less likely to move/migrate. The dummy for the newly formed states signifies that the selected group of people are more likely to migrate if they live in East Germany (excluding East Berlin).

\subsection{Distance to family members}

In Table 3, the characteristics of working people whose family members live at a greater distance are compared to those with family members in the same town. A separate logit regression model is estimated for each of the four close family members (mother, father, sister, brother), given that the respective family member exists. Separate models are shown for men and women. Independent variables in the models include again the employment status (self-employed vs. employed) and a set of socio-structural features (age, education, household size). The results are reported in odds ratios. 
Table 3: Characteristics of working people with family members at a greater distance (Group 1) to those with family members in the same town (Group 0), odds ratios

\begin{tabular}{|c|c|c|c|c|c|c|c|c|}
\hline & \multicolumn{2}{|c|}{ Mother } & \multicolumn{2}{|c|}{ Father } & \multicolumn{2}{|c|}{ Sister } & \multicolumn{2}{|c|}{ Brother } \\
\hline & $\begin{array}{l}\text { Males } \\
\text { OR(S.E.) }\end{array}$ & $\begin{array}{l}\text { Females } \\
\text { OR(S.E.) }\end{array}$ & $\begin{array}{l}\text { Males } \\
\text { OR(S.E.) }\end{array}$ & $\begin{array}{l}\text { Females } \\
\text { OR(S.E.) }\end{array}$ & $\begin{array}{l}\text { Males } \\
\text { OR(S.E.) }\end{array}$ & $\begin{array}{l}\text { Females } \\
\text { OR(S.E.) }\end{array}$ & $\begin{array}{l}\text { Males } \\
\text { OR(S.E.) }\end{array}$ & $\begin{array}{l}\text { Females } \\
\text { OR(S.E.) }\end{array}$ \\
\hline $\begin{array}{l}\text { Self-employed } \\
\text { (ref.: employed) }\end{array}$ & $\begin{array}{l}1.055 \\
(0.126)\end{array}$ & $\begin{array}{l}1.528 * * * \\
(0.234)\end{array}$ & $\begin{array}{l}1.079 \\
(0.154)\end{array}$ & $\begin{array}{l}1.679 \\
(0.368)\end{array}$ & $\begin{array}{l}1.095 \\
(0.154)\end{array}$ & $\begin{array}{l}1.519 * * \\
(0.297)\end{array}$ & $\begin{array}{l}1.292 * \\
(0.179)\end{array}$ & $\begin{array}{l}1.842 * * * \\
(0.356)\end{array}$ \\
\hline Age (yrs.) & $\begin{array}{l}1.030 * * * \\
(0.005)\end{array}$ & $\begin{array}{l}1.026^{* * * *} \\
(0.005)\end{array}$ & $\begin{array}{l}1.040 * * * \\
(0.006)\end{array}$ & $\begin{array}{l}1.038 * * * \\
(0.005)\end{array}$ & $\begin{array}{l}1.037 * * * \\
(0.005)\end{array}$ & $\begin{array}{l}1.032 * * * \\
(0.005)\end{array}$ & $\begin{array}{l}1.048 * * * \\
(0.005)\end{array}$ & $\begin{array}{l}1.046^{* * *} \\
(0.005)\end{array}$ \\
\hline $\begin{array}{l}\text { Tertiary degree } \\
(\text { yes }=1, \text { no }=0)\end{array}$ & $\begin{array}{l}2.844 * * * \\
(0.250)\end{array}$ & $\begin{array}{l}2.748 * * * \\
(0.261)\end{array}$ & $\begin{array}{l}2.460 * * * \\
(0.439)\end{array}$ & $\begin{array}{l}2.676 * * * \\
(0.298)\end{array}$ & $\begin{array}{l}2.523 * * * \\
(0.273)\end{array}$ & $\begin{array}{l}1.915 * * * \\
(0.211)\end{array}$ & $\begin{array}{l}3.304 * * * \\
(0.366)\end{array}$ & $\begin{array}{l}2.165^{* * *} \\
(0.256)\end{array}$ \\
\hline Number of pers. in hh & $\begin{array}{l}0.902 * * * \\
(0.029)\end{array}$ & $\begin{array}{l}0.871 \\
(0.032)\end{array}$ & $\begin{array}{l}0.864 * * * \\
(0.032)\end{array}$ & $\begin{array}{l}0.845^{* * * *} \\
(0.036)\end{array}$ & $\begin{array}{l}0.986 \\
(0.034)\end{array}$ & $\begin{array}{l}0.939 \\
(0.038)\end{array}$ & $\begin{array}{l}0.931 * * \\
(0.033)\end{array}$ & $\begin{array}{l}0.930 * \\
(0.039)\end{array}$ \\
\hline $\mathrm{n}$ & 2,924 & 2,602 & 2,150 & 1,860 & 1,985 & 1,826 & 2,088 & 1,834 \\
\hline Log-Likelihood & $-1,713$ & $-1,572$ & $-1,279$ & $-1,149$ & $-1,259$ & $-1,182$ & 1,291 & $-1,158$ \\
\hline Pseudo $\mathrm{R}^{2}$ & 0.084 & 0.076 & 0.084 & 0.089 & 0.070 & 0.042 & 0.104 & 0.071 \\
\hline $\mathrm{LR} \mathrm{Chi}^{2}(6)$ & 314.5 & 258.7 & 236.0 & 213.1 & 187.5 & 103.1 & 300.2 & 176.3 \\
\hline
\end{tabular}

Note: SOEP 2006, unweighted data. Control variables: Place of residence in the newly formed states, at present address last year. Significance: $* * * \mathrm{p} \leq 0.01,{ }^{* *} \mathrm{p} \leq 0.05,{ }^{*} \mathrm{p} \leq 0.1$

Source: author's calculation

The limitation of cross-sectional analysis notwithstanding, the findings reveal gender differences in individual's inter-relationship between self-employment and place embeddedness. The estimation results in Table 3 contradict expectations drawn from the literature review in that self-employed entrepreneurs are not more likely to live closer to family members. Instead, the findings indicate that self-employed women in particular tend to live at greater distances from their close family members. More precisely, in the conditional models the odds for living in a place that is a one hour drive or more away from close family member are $52-84 \%$ higher for female self-employed workers relative to female employees, after controlling for all other factors in the models. For men, the model for the (nearest living) brother reveal a significant difference between self-employed and employed workers. As for women, male self-employed entrepreneurs tend to live further from a brother (if they have one) than employees. With respect to the other three close family members no significant difference exists between self-employed men relative to employed men. To conclude, this could either mean that women rather than men tend to become self-employed despite lacking strong ties to close family members or that women enter self-employment because they lack strong ties, for example because they have left an employee job as a 'trailing migrant'. 


\subsection{Entry into self-employment and moves}

We have seen that self-employed entrepreneurs are not—as previous literature suggests—-less likely to move or migrate than employees. This section looks at the relations between an entry into self-employment and moves in order to test whether those who are more rooted in place are more likely to become self-employed. Table 4 provides cross-tabulations exploring flows into self-employment by employment status at $t-1$ and moving status. ${ }^{1}$ The moving status is differentiated by non-movers, movers (of all type of moves together) and inter-regional migrants. The results are displayed separately for men and women except for those who migrated as the cell sizes are too small to compare pre and post move employment status by sex. The descriptive results allow first insights into who is more likely to become selfemployment. The first cell in the matrix, for illustration, indicates that $91.3 \%$ of selfemployed male non-movers remained in self-employment. Individual cross-sectional weights are used to provide more general information for Germany.

Table 4. Flows into self-employment by employment status and moving status at t-1 (row percentages)

\begin{tabular}{|c|c|c|c|c|c|}
\hline \multirow[b]{3}{*}{ Employment status at $t-1$} & \multicolumn{5}{|c|}{ Self-employed at $t$} \\
\hline & \multicolumn{2}{|c|}{ No move $t-1$ to $t$} & \multicolumn{2}{|c|}{$\begin{array}{l}\text { Move } t-1 \text { to } t \\
\text { (all moves) }\end{array}$} & \multirow{2}{*}{$\begin{array}{l}\text { Inter-regional move } \\
\qquad-1 \text { to } t \\
\text { Males \& Females }\end{array}$} \\
\hline & Males & Females & Males & Females & \\
\hline Self-employed & 91.3 & 83.8 & 82.3 & 67.6 & 47.9 \\
\hline Employed & 1.0 & 0.7 & 1.6 & 0.9 & 2.5 \\
\hline Unemployed & 2.4 & 1.4 & 2.8 & 2.3 & $*$ \\
\hline Other, inactive $_{1}$ & 6.2 & 1.6 & 5.6 & 2.2 & $*$ \\
\hline
\end{tabular}

Note: Pooled data SOEP 1996-2009, cross-sectional weights. People aged 18-64. Moves are defined on a wave-on-wave basis. Person-years for full matrix $(4 \times 4)$ : $\mathrm{N}($ male movers $)=6,158 ; \mathrm{N}($ females movers $)=6,658 ; \mathrm{N}$ (inter-regional movers $)=1,284 ; \mathrm{N}($ male non-movers $)=62,866 ; \mathrm{N}($ female non-movers $)=67,279$.

* Percentages are not shown because of small cell sizes in raw data.

${ }_{1}$ Other, inactive=persons in the military service, in sheltered workshops or unpaid family workers and those who stated that they are not in gainfully employment or full time education/apprenticeship/vocational training or retired.

Source: author's calculation

\footnotetext{
${ }^{1}$ The full $4 \times 4$ employment status matrix for two adjacent waves (because of four employment states: selfemployed, employed, unemployed, other/inactive) is not displayed but can be obtained from the author upon request.
} 
The results in Table 4 suggest that employees who have moved residence are more likely to become self-employed than employees who remained in the same residence between two adjacent years. This applies to both men and women. Moreover, those employees who migrated are most likely to become self-employed post move. Also against expectations, unemployed and inactive men and women are more likely to enter self-employment in situ than employed men and women. For them, self-employment might enable them to remain in their place of residence. In contrast, flows into self-employment from paid employment seem to be positively associated with moves.

To investigate further the effects of moves on an entry into self-employment random effects logit models were applied. A subsample of person-years was extracted from the SOEP waves 1996-2009 that is restricted to person-year observations of individuals who were not selfemployed at $t-1$. The estimation results are displayed in Table 5. In the models, the outcome variable takes the value 1 if a person became self-employed between the waves $t-1$ and $t$, and zero if a person remained in another labour market state. Model 1 includes a move as compared to no move between $t-1$ and $t$ as independent variable; Model 2 includes an interregional move as compared to no inter-regional move. Both models also include a set of socio-structural features as well as a dummy for a residence in the newly formed states. All independent variables are measured at wave $t$-1, i.e. at the wave before the possible transition into self-employment. The figures displayed in the regression table are odds ratios.

The rho statistic indicates that a great extent of the variation of the outcome variable is attributed to unobserved individual-specific features (63\%). This is unsurprising given the large body of literature detailing the psychological characteristics of entrepreneurs (risk taking, culture, etc.) (e.g., Beugelsdijk and Noorderhaven 2005; Freytag and Thurik 2010). Essentially, the high rho value (and the limited explanatory power of the models) validates the 
importance of individual-specific features for becoming self-employed/starting an entrepreneurial business.

Table 5: Probability of becoming self-employed $t-1$ to $t$, random effects, odds ratios

\begin{tabular}{|c|c|c|c|c|}
\hline \multirow[b]{2}{*}{ Features at $t-1$} & \multicolumn{2}{|c|}{ Model 1} & \multicolumn{2}{|c|}{ Model 2} \\
\hline & $\mathrm{OR}$ & S.E. & OR & S.E. \\
\hline Move (all moves, no $=0$, yes $=1$ ) & $1.427 * * *$ & 0.175 & - & - \\
\hline Inter-regional move $($ no $=0$, yes $=1)$ & - & - & $2.351 * * *$ & 0.665 \\
\hline $\operatorname{Sex}($ ref.: men $)$ & $0.424 * * *$ & 0.044 & $0.425 * * *$ & 0.044 \\
\hline Age (years) & $0.983 * * *$ & 0.005 & $0.982 * * *$ & 0.005 \\
\hline \multicolumn{5}{|l|}{$\begin{array}{l}\text { Employment status at } t-1 \\
\text { (ref.: Unemployed) }\end{array}$} \\
\hline Employed & $0.205 * * *$ & 0.026 & $0.206 * * *$ & 0.026 \\
\hline Inactive/others & 1.222 & 0.175 & 1.215 & 0.174 \\
\hline \multicolumn{5}{|l|}{$\begin{array}{l}\text { Household composition } \\
\text { (ref.: } 1 \text { Pers } h \text { ) }\end{array}$} \\
\hline Couple, no children & 0.952 & 0.156 & 0.960 & 0.157 \\
\hline Couple with children & 0.966 & 0.147 & 0.975 & 0.149 \\
\hline Single Parent & 1.151 & 0.269 & 1.158 & 0.271 \\
\hline Others & 1.246 & 0.346 & 1.278 & 0.356 \\
\hline Owner occupation $($ no $=0$, yes $=1)$ & $1.342 * * *$ & 0.132 & $1.294 * * *$ & 0.125 \\
\hline \multicolumn{5}{|l|}{ CASMIN levels } \\
\hline No completed general education & $0.170 * * *$ & 0.061 & $0.170 * * *$ & 0.061 \\
\hline Elementary & $0.184 * * *$ & 0.040 & $0.185 * * *$ & 0.040 \\
\hline Basic vocational & $0.297 * * *$ & 0.044 & $0.298 * * *$ & 0.044 \\
\hline Middle general & $0.253 * * *$ & 0.076 & $0.253 * * *$ & 0.076 \\
\hline Middle vocational & $0.348 * * *$ & 0.049 & $0.349 * * *$ & 0.049 \\
\hline High general & 1.264 & 0.384 & 1.263 & 0.385 \\
\hline High vocational & $0.600 * * *$ & 0.117 & $0.606 * * *$ & 0.118 \\
\hline Lower tertiary & 0.800 & 0.153 & 0.798 & 0.153 \\
\hline Newly formed states $($ no $=0$, yes $=1)$ & $0.812 * *$ & 0.086 & $0.812 * *$ & 0.086 \\
\hline $\mathrm{N}$ person-year observations (persons) & $92,579(16$ & & $92,579(16$ & \\
\hline $\mathrm{N}$ (moves) & 9,662 & & 995 & \\
\hline Log likelihood & $-5,195$ & & $-5,386$ & \\
\hline Rho (within subject correlation) & 0.627 & & 0.629 & \\
\hline Pseudo $\mathrm{R}^{2}$ & 0.053 & & 0.053 & \\
\hline
\end{tabular}

Notes: Pooled unweighted data SOEP 1996-2009. Moves and employment status are measured on a wave-to-wave basis. Significance: $* * * \mathrm{p} \leq 0.01, * * \mathrm{p} \leq 0.05, * \mathrm{p} \leq 0.1$

Source: author's calculation

The estimation results in Table 5 reveal that the odds of becoming self-employed are significantly increased (by 43\%) for those who moved between $t-1$ and $t$. This pattern holds for inter-regional moves. The odds for those who migrated are almost 2.5 times higher than the odds for those without an inter-regional move. Thus, the results suggest —in complete opposition to the expectation drawn from the literature review-that those who are more spatially mobile are more likely to enter self-employment. 
Furthermore, the estimates show that employed workers have a lower probability to enter selfemployment than those who were previously unemployed or inactive. This finding is in line with the relevance of start-up schemes for the unemployed as a measure of active labour market policy in Germany (Noll and Wießner 2011). The results confirm findings of earlier studies that entering self-employment in Germany is more likely for males and those with higher education/more training (Bögenhold and Fachinger 2007; Lohmann and Luber 2004). Age is negatively associated with an entry into self-employment. This is somewhat surprising, since some studies have shown a positive association of age and self-employment (e.g., Luber et al. 2000; Taylor 1996). However, this may be because these studies compared only the male self-employed with male employees. Household composition has no significant effect on the likelihood to enter self-employment (even if interaction effects with gender are controlled for, not shown). This contradicts previous studies that highlight the importance of the partnership and household context for self-employment (Abraham 2006). The positive association of owner-occupation and self-employment which was found for Britain (Robson 1998; Taylor 1996) appears also valid for Germany. In the conditional models owner occupation increases the odds of entering self-employment by $29-34 \%$, all other factors and individual-specific features equal. Indeed, $56 \%$ of the self-employed compared to $46 \%$ of the employees are owner occupiers (SOEP 1996-2009, weighted data, not shown). This could suggest that housing wealth facilitate an entry into self-employment as previous research suggest for the UK (Disney and Gathergood 2009; Henley 2005). On the other hand, this could indicate that owning one's home enhances entrepreneurial activities, for instance a separate study room in the house or an attached garage. The odds for the dummy for the newly formed states are significantly lower 1, indicating that people in eastern Germany have a lower propensity to become self-employed as compared to those in western Germany. 


\section{Discussion and conclusion}

The findings support the proposition of Harrison et al. (2004, p. 1048) that previous literature has overemphasised the rootedness or embeddedness of self-employment/entrepreneurship. The present results drawn from the German Socio-Economic Panel Study (SOEP) for 19962009 provide empirical evidence that self-employed entrepreneurs in general are not 'rooted' in place and that those who are more 'rooted' in their place of residence are not more likely to become self-employed. Virtually no evidence confirms the hypotheses drawn from the literature review. In summary, (1) self-employed entrepreneurs are not more likely to remain in their place of residence than employees, (2) business founders have not a lower propensity to move than those in continuous paid employment, (3) self-employed entrepreneurs are not more likely to live in close geographical proximity to family members than employees, (4) those who do not move are not more likely to become self-employed and, more specifically, employees who did not move are not more likely to enter self-employment than non-moving employees.

This contradicts the previous findings of Hanson (2003) and Michelacci and Silva (2007). Previous studies may have found a particularly strong rootedness in place among selfemployed entrepreneurs due to their research design. Most studies lack a comparative analysis (i.e. the cross-checking through control groups). This might have led to an underestimation of the residential rootedness of the broader working population. In addition, most studies in entrepreneurship research only looked at business founders in certain industries and/or regions or entrepreneurs who employ other workers and did not apply a life-course perspective on self-employment/entrepreneurship. Consequently, in most studies self-employed entrepreneurs who only employ themselves (including self-employed professionals and freelancers) were not comprehensively sampled with respect to their relations to former places of residences and work. However, in Germany, half of the self-employed men and two-thirds of 
the self-employed women did not employ other workers in 2009 (annual average of quarterly data of the Eurostat Labour Force Survey, own calculation). The figures are even higher in other EU-countries, for example, the Netherlands and the UK.

Three explanations for the finding that self-employed entrepreneurs are fairly geographical mobile and that particularly flows into self-employment are positively associated with interregional moves appear likely. First, as with social mobility patterns in the wage and salary sector (Savage 1988), self-employment/entrepreneurship might require spatial moves for career advancement. This is supported by literature which highlights the importance of work experiences for self-employment/entrepreneurship (e.g., Feldman 2001, Knight and McKay 2000).

Second, household- and family-related constraints might not only hinder moves and thus enhance setting up a business in situ as Feldman (2001) has argued. Instead, the present finding that self-employed women tend to live at a greater distance to close family members as compared to females in paid employment suggest that women might often become selfemployed because they migrated and despite — or due to - their lack of localised strong ties. Several studies provide evidence for the negative labour market consequences of tied migration for women (e.g., Boyle et al. 2003, 2009; Cooke 2008; Rabe 2009; Taylor 2007). Thus, tied moves with a male partner or moves made after a period of living apart over long distances could be an issue for women's decision to enter self-employment. This contradicts the strong ties hypothesis for female self-employment/entrepreneurship (Ekinsmyth 2011; Hanson 2009).

Third, given the rise of self-employment in creative industries like media/broadcasting, the press and consulting in Germany and other post-industrial economies (Baines and Robson 2001; Dex et al. 2000; Gottschall and Kroos 2003), it seems tempting to argue in favour of Florida's (2002) creative class theory. People in certain occupations with specific life style 
preferences might enter self-employment because they want to live in a particular place/region.

To conclude, the present results point to the need for a longitudinal perspective on individual employment careers in order to better understand who becomes self-employed and in what circumstances. It also highlights the importance of individual and household constraints and preferences for entrepreneurship/self-employment. As regards individual and household constraints, partner- and family-related moves could contribute to the higher incidence of necessity-driven start-ups amongst women compared to men (for Germany see, for example, Wagner 2005). It may be necessary to use different methods to consider this issue in future research, since in existing panel surveys there are often too few migration events to analyse how internal migration relates to household composition/partnership status and employment status changes. With respect to individual preferences, empirical research linking individual location preferences of self-employed entrepreneurs and the concept of the 'creative class' could be extremely fruitful not only for understanding why so many people move before they become self-employed but also for a better understanding of what creates 'creative' cities and regions. On the other hand, not only urban agglomerations might play a significant role here but also rural areas or the 'urbanised countryside' with high open space amenities (Fielding 1992). However, the context-dependence of both self-employment and individuals' geographical mobility behaviour (country-specific labour markets, education/housing market systems, etc.) might result in differences in the people-place relations of selfemployment/entrepreneurship in differing country-specific contexts that were not accounted for in the present paper. This should be considered in future research in order to gain a more complete picture of the place embeddedness of self-employed entrepreneurs in different geographical, economic and institutional contexts. 


\section{Acknowledgements}

The work on this paper was funded by a Marie Curie grant from the European Commission within the 7th Framework Program (ID 252752). I am grateful to Bill Clark, Donald Houston, Rory Coulter and Lee Williamson for comments on an earlier version of this paper.

\section{References}

Abraham, M. (2006). Berufliche Selbständigkeit. Die Folgen für Partnerschaft und Haushalt, Wiesbaden: VS-Verlag.

Acs, Z. J., \& Armington, C. (2004). Employment Growth and Entrepreneurial Activity in Cities. Regional Studies, 38, 911-927.

Armington, C., \& Acs, Z. J. (2002). The determinants of regional variation in new firm formation. Regional Studies, 36, 33-45.

Audretsch, D. B., Falck, O., Feldman, M. P., \& Heblich, S. (2010). Local Entrepreneurship in Context. Regional Studies, doi:10.1080/00343404.2010.490209

Baines, S., \& Robson, L. (2001). Being self-employed or being enterprising? The case of creative work for the media industries. Journal of Small Business and Enterprise Development, 8, 349-362.

Bathelt, H., \& Glückler, J. (2002). Wirtschaftsgeographie. Ökonomische Beziehungen in räumlicher Perspektive. Eugen Ulmer: Stuttgart.

Bergmann, H., \& Sternberg, R. (2007). The Changing Face of Entrepreneurship in Germany. Small Business Economics, 28, 205-221.

Beugelsdijk, S., \& Noorderhaven, N. (2005). Personality Characteristics of Self-Employed; An Empirical Study. Small Business Economics, 24, 159-167.

Blanchflower D. G. (2000). Self-employment in OECD countries. Labour Economics, 7, 471505.

Blanchflower, D. G., \& Meyer, B. D. (1994). A Longitudinal Analysis of the Young SelfEmployed in Australia and the United States. Small Business Economics, 6(1), 1-9.

Bögenhold, D., \& Fachinger, U. (2007). Micro-firms and the margins of entrepreneurship: The restructuring of the labour market. The international Journal of Entrepreneurship and Innovation, 8, 281-292.

Bönte, W., Falck, O., \& Heblich, S. (2009). The Impact of Regional Age Structure on Entrepreneurship. Economic Geography, 85, 269-287.

Boyle, P., Cooke, T., \& Smith, D. (2003). The effect of long-distance family migration and motherhood on partnered women's labour-market activity in Great Britain and the USA. Environment and Planning A, 35, 2097-2114.

Boyle, P., Feng, Z., \& Gayle, V. (2009). A New Look at Family Migration and Women's Employment Status. Journal of Marriage and Family, 71, 417-431. 
Buck, N. (2000). Using panel surveys to study migration and residential mobility. In D. Rose (Ed.), Researching social change: The uses of household panel surveys (pp. 250-272). London: Routledge.

Cooke, T. J. (2008). Migration in a Family Way. Population, Space and Place, 14, 255-265.

Davidsson, P., \& Gordon, S. R. (2011). Panel studies of new venture creation: a methodfocused review and suggestions for future research. Small Business Economics, doi: 10.1007/s11187-011-9325-8.

Delgado, M., Porter, M. E., \& Stern, S. (2010). Clusters and entrepreneurship. Journal of Economic Geography, 10, 495-518.

Dex, S., Willis, J., Paterson, R., \& Sheppard, E. (2000). Freelance Workers and Contract Uncertainty: The effects of Contractual Changes in the Television Industry. Work, Employment \& Society, 14, 283-305.

Disney, R., \& Gathergood, J. (2009). Housing wealth, liquidity constraints and selfemployment. Labour Economics, 16, 79-88.

Ekinsmyth, C. (2011). Challenging the boundaries of entrepreneurship: The spatialities and practices of UK 'Mumpreneurs'. Geoforum, 42, 104-114.

Feldman, M. (2001). The Entrepreneurial Event Revisited: Firm Formation in a Regional Context. Industrial and Corporate Change, 10, 861-891.

Feldman, M. P., Francis, J., \& Bercovitz, J. (2005). Creating a Cluster While Building a Firm: Entrepreneurs and the Formation of Industrial Clusters. Regional Studies, 39, 129-141.

Fieding, A. J. (1992). Migration and Social Mobility: South East England as an Escalator Region. Regional Studies, 26(1), 1-15.

Florida, R. (2002). The Rise of the Creative Class. Basis Books: New York.

Frees, E. W. (2004). Longitudinal and Panel Data. Analysis and Applications in the Social Sciences. Cambridge: Cambridge University Press.

Freytag. A., \& Thurik, A. R. (Eds.) (2010). Entrepreneurship and Culture. Berlin, Heidelberg: Springer.

Fritsch, M., \& Schindele, Y. 2011. The Contribution of New Businesses to Regional Employment - An Empirical Analysis. Economic Geography, 87, 153-180.

Georgellis, Y., Sessions, J. G., \& Tsitsianis, N. (2005). Windfalls, Wealth, and the Transition to Self-Employment. Small Business Economics, 25, 407-428.

Glückler, J. (2007). Economic geography and the evolution of networks. Journal of Economic Geography, 7, 619-634.

Gottschall, K., \& Kroos, D. (2003). Self-Employment in Germany and the UK. Labor Market Regulation, Risk-Management and Gender in Comparative Perspective. ZeS-

Arbeitspapier 13. Bremen: Zentrum für Sozialpolitik.

Hanson, S. (2003). Geographical and Feminist Perspectives on Entrepreneurship. Geographische Zeitschrift, 91, 1-23.

Hanson, S. (2009). Changing Places Through Women's Entrepreneurship. Economic Geography, 85, 245-267.

Hanson, S., \& Blake, M. (2009). Gender and Entrepreneurial Networks. Regional Studies, 43, $135-149$. 
Harrison, R. T., Cooper, S. Y., \& Mason, C. M. (2004). Entrepreneurial Activity and the Dynamics of Technology-based Cluster Development: The Case of Ottawa. Urban Studies, 41, 1045-1070.

Henley, A. (2005). Job Creation by the Self-employed: The Roles of Entrepreneurial and Financial Capital. Small Business Economics, 25, 175-196.

Jack, S. (2005). The role, use, and activation of strong and weak network ties: a qualitative analysis. Journal of Management Studies, 42, 1233-1259.

Joona, P. A., \& Wadensjö, E. (2011). The best and the brightest or the least successful? Selfemployment entry among male wage-earners in Sweden. Small Business Economics, doi: 10.1007/s11187-011-9365-0.

Katz, J. A., \& Williams, P. M. (1997). Gender, self-employment and weak-tie networking through formal organizations. Entrepreneurship and Regional Development, 9, 183-197.

Knight, G., \& McKay, S. (2000). Lifetime Experiences of Self-Employment. Department of Social Security Research Report No. 120. Huddersfield, UK.

Kohler, U. \& Kreuter, F. (2009). Data Analysis Using Stata. $2^{\text {nd }}$ edition. College Park: Stata Press.

Lohmann, H., \& Luber, S. (2004). Trends in Self-Employment in Germany: Different Types, Different Developments? In R. Arum \& W. Müller (Eds.), The Reemergence of SelfEmployment. A Comparative Study of Self-Employment Dynamics and Social Inequality (pp. 36-74). Princeton and Oxford: Princeton University Press.

Luber, S., Lohmann, H., Müller, W., \& Barbieri, P. (2000). Male self-employment in four European countries. International Journal of Sociology, 30, 5-44.

Malmberg, A., \& Maskell, P. (2002). The elusive concept of localization economies: towards a knowledge-based theory of spatial clustering. Environment and Planning A, 34, 429449.

Michelacci, C., \& Silva, O. (2007). Why So Many Local Entrepreneurs? The Review of Economics and Statistics, 89, 615-633.

Millán, J. M., Congegado, E., \& Román, C. (2010). Determinants of self-employment survival in Europe. Small Business Economics, doi: 10.1007/s11187-010-9260-0.

Mueller, P. (2006). Entrepreneurship in the Region: Breeding Ground for Nascent Entrepreneurs? Small Business Economics, 27, 41-58.

Niittykangas, H., \& Tervo, H. (2005). Spatial Variations in Intergenerational Transmission of Self-employment. Regional Studies, 39, 319-332.

Nijkamp, P. (2003). Entrepreneurship in a Modern Network Economy. Regional Studies, 37, 395-405.

Noll, S., \& Wießner, F. (2011). Sweet and Bitter. Why female Entrepreneurs often have high Survival Rates but low Incomes. Sozialer Fortschritt/German Review of Social Policy (forthcoming).

Oberschachtsiek, D. (2010): The experience of the founder and self-employment duration: a comparative advantage approach. Small Business Economics, doi: 10.1007/s11187-0109288-1.

Parker, S. C. (1997). The Effects of Risk on Self-employment. Small Business Economics, 9, 515-522. 
Parker, S. C. (2006). Entrepreneurship, Self-Employment and the Labour Market. In M. Casson, B. Yeung, A. Basu \& N. Wadeson (Eds.). Oxford Handbook of Entrepreneurship (pp. 435-460). Oxford: Oxford University Press.

Rabe, B. (2009). Dual-earner migration. Earnings gains, employment and self-selection. Journal of Population Economics, 24, 477-497.

Rabe, B., \&Taylor, M. P. (2010). Residential mobility, quality of neighbourhood and life course events. Journal of the Royal Statistical Society A, 173, 531-555.

Reynolds, P. D. (1997). Who Starts New Firms? - Preliminary Explorations of Firms-inGestation. Small Business Economics, 9, 449-462.

Robson, M. T. (1998). Self-employment in the UK regions. Applied Economics, 30, 313-322.

Romanelli, E., \& Schoonhaven, C. B. (2001). The local origins of new firms. In C. B. Schoonhaven \& E. Romanelli (Eds.), The Entrepreneurship Dynamic: Origins of Entrepreneurship and the Evolution of Industries (pp. 40-67). Stanford: Stanford University Press.

Savage, M. (1988). The missing link? The relationship between spatial mobility and social mobility. The British Journal of Sociology, 39(4), 554-577.

Scott, A. J. (2006). Entrepreneurship, Innovation and Industrial Development: Geography and the Creative Field Revisited. Small Business Economics, 26, 1-24.

Shutt, J., \& Sutherland, J. (2003). Encouraging the Transition into Self-employment. Regional Studies, 37, 97-103.

Solga, H. (2001). Longitudinal Surveys and the Study of Occupational Mobility: Panel and Retrospective Design in Comparison. Quality \& Quantity, 35, 291-309.

Sorenson, O., \& Audia, P. G. (2000). The social structure of entrepreneurial activity: geographic concentration of footwear production in the United States 1940-1989. American Journal of Sociology, 106, 424-462.

Stam, E. (2007). Why Butterflies Don't Leave. Locational behaviour of Entrepreneurial Firms. Economic Geography, 83, 27-50.

Tamásy, C. (2006). Determinants of Regional Entrepreneurship Dynamics in Contemporary Germany: A Conceptual and Empirical Analysis. Regional Studies, 40, 365-384.

Taylor, M. P. (1996). Earnings, independence or unemployment: Why become selfemployed? Oxford Bulletin of Economics and Statistics, 58, 253-266.

Taylor, M. P. (1999). Survival of the fittest? An analysis of self-employment duration in Britain. The Economic Journal, 109, C140-C155.

Taylor, M. P. (2007). Tied Migration and Subsequent Employment: Evidence from Couples in Britain. Oxford Bulletin of Economics and Statistics, 69, 795-818.

Thornton, P., \& Flynn, K. (2003). Entrepreneurship, networks, and geographies. In D. Acs (Ed.), Handbook of Entrepreneurship Research: An Interdisciplinary Survey and Introduction (pp. 401-433). Boston, MA: Kluwer.

Varga, A., \& Schalk, H. (2004). Knowledge Spillovers, Agglomeration and Macroeconomic Growth: An Empirical Approach. Regional Studies, 38, 977-989. 
Wagner, J. (2005). "Der Noth gehorchend, nicht dem eignen Trieb"-Nascent Necessity and Opportunity Entrepreneurs in Germany: Evidence from the Regional Entrepreneurship Monitor (REM). IZA Discussion Paper Series No. 1608. Bonn: Institute for the Study of Labor.

Wagner, J. (2007). What a Difference a Y makes-Female and Male Nascent Entrepreneurs in Germany. Small Business Economics, 28, 1-21.

Wai-chung Yeung, H. (2009). Transnationalizing entrepreneurship: a critical agenda for economic geography. Progress in Human Geography, 33, 210-235. 


\section{Appendix}

Table A1. Sample description of self-employed entrepreneurs by sex, SOEP 1996-2009

\begin{tabular}{|c|c|c|c|}
\hline & Total & Males & Females \\
\hline $\operatorname{Sex}(\%)$ & 100.0 & 66.1 & 33.9 \\
\hline Age, mean (std. dev.) & $45.1(9.5)$ & $45.3(9.7)$ & $44.6(9.2)$ \\
\hline $\begin{array}{l}\text { Marital status }(\%) \\
\text { Married, living together } \\
\text { Separated, married } \\
\text { Never married } \\
\text { Divorced } \\
\text { Widowed }\end{array}$ & $\begin{array}{l}69.0 \\
2.8 \\
17.2 \\
9.7 \\
1.3\end{array}$ & $\begin{array}{l}68.9 \\
2.6 \\
19.1 \\
8.7 \\
0.7\end{array}$ & $\begin{array}{l}69.3 \\
3.2 \\
13.3 \\
11.7 \\
2.5\end{array}$ \\
\hline Owner-occupation of household (\%) & 62.7 & 63.3 & 61.5 \\
\hline $\begin{array}{l}\text { Household type }(\%) \\
\text { One-person-household } \\
\text { Couple no children } \\
\text { Couple with children } \\
\text { Single Parent } \\
\text { Others }\end{array}$ & $\begin{array}{l}12.6 \\
25.4 \\
55.0 \\
4.0 \\
2.9\end{array}$ & $\begin{array}{l}13.2 \\
25.3 \\
56.6 \\
1.9 \\
3.0\end{array}$ & $\begin{array}{l}11.5 \\
25.6 \\
52.0 \\
8.1 \\
2.8\end{array}$ \\
\hline $\begin{array}{l}\text { CASMIN Levels }(\%)_{1} \\
\text { No completed general education } \\
\text { Elementary } \\
\text { Basic vocational } \\
\text { Middle general } \\
\text { Middle vocational } \\
\text { General maturity certificate } \\
\text { Vocational maturity certificate } \\
\text { Lower tertiary } \\
\text { Higher tertiary }\end{array}$ & $\begin{array}{l}0.6 \\
3.2 \\
22.0 \\
1.8 \\
25.9 \\
3.3 \\
7.6 \\
9.0 \\
26.7\end{array}$ & $\begin{array}{l}0.7 \\
3.0 \\
25.3 \\
1.7 \\
24.4 \\
3.6 \\
6.9 \\
10.0 \\
24.5\end{array}$ & $\begin{array}{l}0.5 \\
3.5 \\
15.5 \\
2.1 \\
28.7 \\
2.5 \\
8.9 \\
7.2 \\
31.0\end{array}$ \\
\hline Length of education in years (median, sd) & $13.3(2.9)$ & $13.2(2.9)$ & $13.6(2.9)$ \\
\hline $\begin{array}{l}\text { Types of self-employment }(\%) \\
\text { Agricultural self-employed workers } \\
\text { Non-agricultural solo self-employed workers } 2 \\
\text { Professionals (incl. freelance) }\end{array}$ & $\begin{array}{l}4.5 \\
46.9 \\
28.3\end{array}$ & $\begin{array}{l}5.2 \\
39.7 \\
25.4\end{array}$ & $\begin{array}{l}3.1 \\
61.0 \\
34.0\end{array}$ \\
\hline Newly formed States $(\%)_{3}$ & 30.3 & 30.5 & 30.0 \\
\hline $\mathrm{N}$ (person-year observations) & 11,935 & 7,894 & 4,041 \\
\hline
\end{tabular}

Note: Pooled unweighted data SOEP 1996-2009. Only person-years with information on employment status, moving status, and region of residence.

${ }_{1}$ International educational classification which considers the level of education in terms of length of educational experience and required abilities (elementary, secondary, higher) together with the vocational oriented qualification.

${ }_{2}$ Solo self-employed workers are those without employees.

${ }_{3}$ Without East Berlin

Source: author's calculation 